\title{
What's new in IUGR from the endocrinological point of view?
}

Co nowego w IUGR w aspekcie endokrynologicznym?

\author{
Alicja Korpysz ${ }^{1}$, Mieczysław Szalecki²
}

${ }^{1}$ Outpatient Clinic of Endocrinology and Diabetology, Children's Memorial Health Institute, Warsaw, Poland

${ }^{2}$ Department of Endocrinology and Diabetology, Children's Memorial Health Institute, Warsaw, Poland

\begin{abstract}
Genetic causes of IUGR: The IGF 2 gene encoding IGF2 synthesis contributes to growth of the foetus. The maternal genes PHLDA2, GRB10, and placental ALS also play a role in the regulation of foetal growth. CDKN1C mutation can lead to IUGR. In SRS syndrome, apart from epimutation 11p15 and disomy 7, the cause may be a mutation of HMAGA2-PLAG1-IGF2 genes. Growth deficiency: in $10 \%$ of children with IUGR with growth deficiency, ACAN gene mutation (aggrecan gene) was described. Children with IUGR and with dynamic evolution of puberty can achieve better final growth through combined therapy with $\mathrm{GH}$ and $\mathrm{GnRH}$ analogues. Insulin resistance: In light of new reports, oxidative stress during pregnancy, epigenetic regulation in the foetal period in children with IUGR, and insulin resistance both peripheral and central during "catch up growth" are observed.
\end{abstract}

Key words:

IUGR, growth deficit, insulin resistance.

\section{Streszczenie}

Genetyczne przyczyny IUGR: Gen IGF 2 kodujący syntezę IGF2 przyczynia się do wzrastania płodu. Rolę w regulacji wzrastania płodu odgrywają także geny matczyne: PHLDA2, GRB10, oraz łożyskowe ALS. Mutacja CDKN1C może prowadzić do IUGR. W zespole SRS prócz epimutacji 11p15 oraz disomii 7, przyczyną może być mutacja genów HMAGA2-PLAG1-IGF2.

Niedobór wzrostu: u 10\% dzieci z IUGR z niedoborem wzrostu opisana została mutacja genu ACAN (aggrecan gene). Dzieci z IUGR i z dynamiczną ewolucją dojrzewania mogą uzyskać lepszy wzrost końcowy dzięki terapii łączonej GH i analogiem GnRH.

Insulinooporność: W świetle nowych doniesień upatrywane są: stres oksydacyjny w czasie ciąży, epigenetyczna regulacja w okresie płodowym u dzieci z IUGR oraz obwodowa i centralna oporność na insulinę w okresie catch up growth.

\section{Słowa kluczowe:}

IUGR, niedobór wzrostu, insulinooporność. 


\section{Introduction}

Intrauterine growth retardation/small for gestational age (IUGR/SGA) is too low birth weight and/or length ( $<-2 \mathrm{SD}$ ) compared to gestational age, for gender and population. Intrauterine growth retardation is an intrauterine restriction of foetal growth. Small for gestational age is a state of deficiency in weight and/or body length of a newborn for gestational age. The limit criterion for weight and/or body length of a child born with SGA/IUGR is the value of one or both of these parameters less than -2 SDS in relation to the population reference standards for a given gestational age and gender. The term SGA is not synonymous with IUGR. Even if the causes leading to impaired foetal growth are known, a newborn baby may not meet the SGA criteria, and a deficiency in weight and/or body length may also be constitutionally determined. Nevertheless, the usual interchangeable use of IUGR/SGA terms is common in the literature. The article covers the problem of children with IUGR.

This group should be under special endocrinological care. Thirteen percent of children born with IUGR do not "catch up" with normal growth, i.e. do not reach body height greater than -2 SDS ( $<3^{\text {rd }}$ centile) during the first two to four years after birth. IUGR is associated with more frequent occurrence of obesity, lipid and carbohydrate metabolism disorders, including type 2 diabetes mellitus, hypertension, and other cardiovascular diseases [18-24].

\section{Genetically determined causes of the IUGR}

According to the study by Dunger [1] from 2006, the /GF 2 gene encoding IGF2 synthesis contributes to foetal growth in mice, whereas the IGF2R gene encoding IGF2R receptor may cause intrauterine growth retardation. The maternal H19 gene, which regulates the expression of the IGF2 gene, is of great importance for the regulation of birth weight. The $\mathrm{H} 19+2992$ variant correlates with the increase in IGF2 concentration and controls foetal growth [1]. In foetuses with intrauterine growth retardation, not only decreased concentrations of insulin-like growth factors, i.e. IGF1 and IGF2, are observed, but also decreased concentrations of proteins that bind IGF1. A positive correlation between the levels of IGFBP3 (insulin-like growth factor-binding protein) and a negative correlation between the levels of IGFBP1 and birth weight have been documented [2]. In foetuses with IUGR a positive correlation of leptin and insulin levels as well as with IGF1 and IGFBP3 levels was also found [3]. Maternal genes play an important role in the regulation of foetal growth: PHLDA2 (pleckstrin homology-like domain-family A member) takes part in the regulation of placental growth, GRB10 (growth receptor binding protein) is a protein associated with the signal transmission of insulin receptor, and IGF1 receptor inhibits the signal [4] and placental ALS (acid-labile subunit), the protein binding IGF1, responsible for its half-life [5]

CDKN1C (cyclin-dependent kinase inhibitor 1C) is a gene, a regulator of cell proliferation, including pancreatic $\beta$ cells. The Kerns' study shows that CDKN1C mutation (chromosome 11p15) can lead to a reduction in foetal growth, growth deficiency, and early onset of diabetes in adults with IUGR [6].

Methylation disorders (epigenetics) are essential in creating inhibition of intrauterine growth. About $60 \%$ of SRS syndrome is caused by hypomethylation of the ICR1 region of chromosome 11 p15 and maternal disomy of chromosome 7 (UPD 7) [7], often associated with the occurrence of asymmetry in this syndrome. In 2017 a paper by Netchene et al. was published, in which the authors reported on mutation of HMAGA2-PLAG1-IGF2 genes. Apart from epimutation in chromosome 11 p15 (gene IGF2/ H19) and chromosome 7 disomy, SRS may also be caused by mutations of genes that control IGF2 expression. HMGA2 (DNA binding protein high-mobility group AT-hook 2) is identified in chromosome 12q14, the deficiency of which provokes inhibition of intrauterine growth. PLAG1 (pleomorphic adenoma gene 1), (chromosome 8q12) also implies cell growth. The mutation of HMGA2-PLAG1-IGF2 leads to decreased expression of IGF2 gene in SRS. Reduced IGF2 expression may additionally be caused by lack of activation of the P3 IGF2 promoter due to PLAG1 and HMGA2 interaction. The presence of HMGA2 and PLAG1 mutations in both parents may cause $50 \%$ risk of SRS. HMGA2 gene defect is also a cause of lower birth weight and higher head circumference in children with SRS syndrome. The process is associated with lower IGF2 levels [8].

\section{Growth deficiency}

Thirteen per cent of children born with IUGR do not "catch up" with proper growth, i.e. they do not reach a body height greater than -2 SDS ( $<3^{\text {rd }}$ centile) in the period from two to four years after birth "non catch up growth" [9]. Abnormalities in the $\mathrm{GH} / \mathrm{IGF} 1$ axis in children born as IUGR can be divided into the following: with low levels of GH, IGF1, IGFBP3; with decreased sensitivity to $\mathrm{GH}$; with normal levels of $\mathrm{GH}$, low levels of IGF1, IGBP3, and with decreased sensitivity to IGF1; and with high levels of GH and IGF1. The main objective of growth hormone use in this group is to achieve proper final growth and improve the quality of life, especially in adulthood [10]. In the IUGR group treated with growth hormone and in the untreated group, no differences in carbohydrate metabolism were found after the therapy was finished. Breukhoven, in a group of 377 children with IUGR, proved that there were no differences in body mass composition in young adults after the therapy and without it [11]. Also, no differences were found in the response to insulin sensitivity in children with IUGR with exon $3 \mathrm{GH}$ receptor (d3/fl-GHR) deletion and without deletions treated with growth hormone [12]. The thyreological parameters during the treatment with growth hormone in children with IUGR were not clinically significant in comparison with the pre-treatment period [13]. Muscle strength and bone density were similar in children with IUGR and SNP during growth hormone therapy [14].

In some children with IUGR, bone age advances faster during the growth hormone therapy. In this group, the mutation of the ACAN gene (aggrecan gene) was described. The mutation is also associated with the following: slight dysplasia with 
proportional disorders, brachydactylia, osteoarthritis, and dysfunction of the articular cartilage. In the study by Manouk van der Steen et al. among 290 IUGR children treated with growth hormone, the above-mentioned mutation was identified in 29 of them, i.e. in $10 \%$ [15].

The same authors, similarly to Hagen-Kollega, emphasised the use of a combined therapy of growth hormone and $\mathrm{GnRH}$ analogue in children born with IUGR with growth deficiency and early, rapidly progressing puberty.

Children with IUGR and dynamic evolution of puberty can achieve better final growth due to combined therapy [16]. No differences in insulin resistance were found in the IUGR group treated only with growth hormone in comparison with children undergoing combined therapy [17].

\section{Insulin resistance}

There are many hypotheses of insulin resistance in children with IUGR. Barker proposed the thrifty phenotype hypothesis. A "survival" hypothesis was developed, which assumed peripheral insulin resistance in order to redistribute glucose to the most important organs (brain) of a malnourished foetus [19]. According to Czernichow, the cause of insulin resistance in children with IUGR was the interaction of foetal development and genetic factors $[20,21]$. A number of gene polymorphisms were found that could be responsible for this phenomenon gene polymorphisms: INS VNTR (insulin gene variable number tandem repeat), IGF-I, PPAR- $\gamma 2 /$ Pro 12 Ala (peroxisome proliferator-activated receptor), ACE //D (angiotensin I-converting enzyme), CDKN1C (cyclin-dependent kinase inhibitor1c), or glucokinase gene [22, 23]. In the mechanism of insulin resistance in children with IUGR, the direct cause of impaired insulin receptor function is abnormal phosphorylation of tyrosine kinase of the $\beta$-receptor subunit [24]. There are reports of a decrease in GLUT4 (glucose transporter) and GLUT1 levels in muscle tissue in the foetal period as causes of insulin resistance [24, 25]. The observations of scientists drew attention not only to the undernutrition in the foetal period, but also to the postnatal weight gain as one of the possible causes of metabolic disorders in later life [26-28]. Many studies prove that insulin resistance in a child with IUGR may be associated with increased IGF1 and BMI levels during postnatal catch-up growth [26-28]. Particularly BMI and the amount of visceral adipose tissue associated with it may be an essential factor in the development of insulin resistance after birth in these children [28].

New reports also highlight both the foetal and postnatal period in the development of insulin resistance in children with IUGR.

Lakshmy suggests a major role of oxidative stress during pregnancy as a result of malnutrition [29]. Oxidative stress may be associated with an increase in the concentration of acid metabolites: 2 hydroxy-butyric acid and $\gamma$-glutamyl leucine during calorie restriction in pregnancy, resulting in insulin resistance in the child [30].

Physiological stress during pregnancy is also of great importance for the development of metabolic syndrome in children with IUGR. The result is an increase in the expression of adrenal steroidogenesis [31]. Cheong [32] describes the increase in $M C 2 R$ gene expression in adrenal glands of mice mothers with IUGR as the cause of subsequent metabolic disorders.

Joung's paper suggested the role of the AFABP protein (adipocyte fatty acid-binding protein) in umbilical cord blood related to the increased risk of metabolic syndrome and cardiac disorders in adults born with IUGR [33]. The placental insufficiency is also a possible cause of carbohydrate metabolism disorders as a result of increased production of glucose in the liver of foetuses with IUGR [34].

In light of new reports, epigenetic regulation of the foetal period of IUGR in mice is also observed.

Excessive expression of the microRNA-29a coactivator-1 $\alpha$ PPAR $\delta$ receptor (peroxisome proliferator - activated receptor $\gamma$-coactivator-1 $\alpha$ PGC-1 $\alpha$ ) responsible for transmitting the PPAR//PGC-1 $\alpha$ signal reduces glucose utilisation in the cell and the production of ATP. The result is a decrease in GLUT4, which has already been reported as a cause of insulin resistance [35]. Epigenetic regulation related to foetal malnutrition, pancreatic $B$ cell dysfunction, changed insulin metabolism, and consequently obesity and TD2 was described by Vaiserman [36]. Among the epigenetic causes of IUGR, there was a report of caloric restriction of the mother leading to carbohydrate disturbances in rats with intrauterine growth restriction, e.g. by increasing the methylation of the co-activator- $1 \alpha$ PPAR $\delta$ receptor, PGC1 $\alpha$ [37]. There is a reduced receptor sensitivity to insulin and glucose intolerance. In mothers with a calorie-limited diet, a decreased expression of p53 /IGFBP3 of the signal IGFBP3/IGF-1/IRS-1/Akt in peripheral tissues may also occur, leading to abnormal glucose metabolism and, consequently, insulin resistance in mice with IUGR. The process concerns the "catch up growth" period [38]. Xing proved that the decreased PI3K/Akt signal and consequently the decreased expression of GLUT4 in rat muscles with IUGR during the "catch up growth" period leads to insulin resistance [39]. Jones, however, found increased expression of genes TRB3, JUN, MYC, and SGK1 and decreased expression of PTPRD as the cause of increased glucose production in the liver of the sheep foetuses with IUGR and, consequently, insulin resistance [40]. One recent report highlights the role of methylation and expression of placental and umbilical cord genes in foetuses with IUGR, involved in the regulation of carbohydrate homeostasis and lipid metabolism, affecting foetal growth, weight composition, and risk of diabetes in adulthood [41]. Hypermethylation and lower activation of the ATG2B gene (autophagy-related 2B) in the placenta and umbilical cord blood may be associated with low birth weight and abnormal adipogenesis leading to lower body fat. NKX6.1 (transcription factor associated with $\beta$ pancreatic cell differentiation), hypermethylation of the gene and its lower activation in the placenta and umbilical cord are accompanied by low birth weight and low insulin secretion. The SLC13A5 gene (encoding sodium citrate transporter mainly in hepatocytes) is associated with carbohydrate metabolism and lipogenesis. Reduced gene expression leads to disturbances in lipogenesis and reduction of foetal mass growth in the form 
of higher fatty acid oxidation and reduction of liver lipogenesis. The reduction of gene expression may protect the foetus from excessive growth of adipose tissue during the "catch up growth" period and thus from insulin resistance during this period [42]. "Catch up growth" in children with IUGR, may induce not only insulin resistance but also adrenarche praecox and later fertility problems [43].

The issue of postnatal "catching up" with growth as a cause of insulin resistance, as discussed earlier, has been confirmed in modern studies, especially the role of the hypothalamuspituitary axis.

Berends et al. [44] found peripheral and central insulin resistance in hypotrophic mice during the "catch up growth" period. The changes concerned the decreased concentration of PI3K subunit (phosphoinositide 3-kinase - p110 3 ) and consequently increased IRS-1 phosphorylation in the arcuate nucleus (ARC) of the hypothalamus. An increase in the expression of the gene encoding tyrosine phosphatase 1B (PTP 1B) in the hypothalamus, leading to central insulin resistance, was also identified.

Fukami proved central insulin resistance in the hypothalamus arcuate nucleus in rats with IUGR. He described the phenomenon associated with reduced expression of the activator of phospho-AMP kinase (PAMPK) and NPY and increased activity of POMC mRNA on anorexigenic activity of insulin administered intravenously. Despite feeding, the state of orexigenic ARC stimulation of the hypothalamus and resistance to anorexigenic insulin effect remained. The end result was hyperphagia and obesity in the IUGR group [45].

An interesting new report on insulin resistance is the observation of the phenomenon in both IUGR and IUGR-AGA

\section{References}

1. Dunger DB, Petry CJ, Ong KK. Genetic variations and normal fetal growth. Horm Res 2006; 65: 34-40. doi: 10.1159/000091504

2. Verhaeghe J, Van Bree R, Van Herck E, et al. C-peptide,insulin- like growth factors I and II, and insulin-like growth factor binding protein-1 in umbilical cord serum: correlations with birth weight. Am Obstet Gynecol 1993; 169: 89-97. doi: 10.1016/0002-9378 (93) 90137-8

3. Leger J, Oury JF, Noel M, et al. Growth factors and intrauterine growth retardation. Serum growth hormone, insulin-like growth factor IGF I, IGF II, and IGF binding protein 3 levels in normally and growth-retarded human fetuses during the second half of gestation. Pediatr Res 1996; 40: 94-100. doi: 10.1203/00006450-19960700000017

4. Moor GE, Ishida M, Demetriou C, et al. The role and interaction of imprinted genes in human fetal growth. Philos Trans R Soc Lond B Biol Sci 2015; 370: 2014-2074. doi: 10.1098/rstb.2014.0074

5. Iñiguez G, Argandoña F, Medina P, et al. Acid-labile subunit (ALS) gene expression and protein content in human placentas: differences according to birth weight. J Clin Endocrinol Metab 2011; 96 : 187-192. doi: 10.1210/jc.2010-0244 groups. Verkauskiene et al. proved that inhibition of intrauterine growth in the foetal period is essential for the development of insulin resistance and metabolic disorders, and not constitutionally determined low birthweight. The aim was to compare insulin resistance parameters in IUGR, constitutional SGA, AGA, and also AGA groups with IUGR-AGA intrauterine inhibition (final birth weight $>10 \mathrm{c}$ ). The authors showed a significant increase in carbohydrate metabolism disorders (insulin resistance based on HOMA index) in IUGR and IUGR-AGA groups. They also demonstrated decreased activity of $11 \beta$ HSD2 in the placenta and consequently increased cortisol concentration in newborns with reduced intrauterine growth [46].

The role of adipocytokines in insulin resistance in IUGR patients has been discussed many times. Insulin resistance in children with IUGR may be related to leptin resistance and hypoadiponectinaemia. Simpson concluded that the concentration of these adipocytokines in umbilical cord blood correlated positively with the amount of adipose tissue at a later age [47]. In Wang's study, lower adiponectin levels may be accompanied by insulin resistance in infants with IUGR [48]. Higher resistin levels in 12-month-old infants with IUGR without "catch up growth" coexisted positively with total cholesterol levels, not with insulin resistance according to Giapros [49]. RBP 4 (retinol-binding protein serum), another adipokine, associated with insulin resistance, seems to play the role of an early marker of IUGR in the third trimester of pregnancy [50].

The above-mentioned studies do not fully cover the metabolic aspect, growth, and the intrauterine process of foetal growth retardation. The dynamism of research and the progression of exploration in this area requires constant broadening of knowledge.
6. Kerns S, Guevara-Aguire J, Andrew S, et al. A novel variant in CD$\mathrm{KN} 1 \mathrm{C}$ is associated with intrauterine growth restriction, short stature and early-adulthood onset diabetes. J Clin Endocrinol Metab 2014; 99: E2117-2122. doi: 10.1210/jc.2014-1949

7. Netchine I, Rossignol S, Dufourg MN, et al. 11 p15 imprinting center region 1 loss of methylation is a common and specific cause of typical Russell Silver syndrome: clinical scoring system and epigenetic-phenotypic correlations. J Clin Endocrinol Metab 2007; 92: 3148-3154. doi: 10.1210/jc.2007-0354

8. Netchine I, Brioude F, Abi Habib W, et al. Syndrome de Silver Russel: Implication de la voie des oncogenes HMGA2- PLAG1-IGF2. Genet Med 2017

9. Albertsson-Wikland K, Boguszewski M, Kalberg J. Children born small for gestational age: postnatal growth and hormonal status. Horm Res 1998; 49: 7-13. doi: 10.1159/000053080

10. Bannink E, Djurhuus CB, Christensen T, et al. Adult height and health-related quality of life after growth hormone therapy in small for gestational age subjects. J Med Econ 2010; 13: 221-227. doi: 10.3111/13696998.2010.484323

11. Breukhoven PE, Kerkhof GF, Van Dijk M, et al. Long-term impact of $\mathrm{GH}$ treatment during childhood on body composition and fat 
distribution in young adults born SGA. J Clin Endocrinol Metab 2011; 96: 3710-3716. doi: 10.1210/jc 2011-1658

12. Audi L, Carrascosa A, Esteban C, et al. The exon 3-deleted/full-length growth hormone receptor polymorphism does not influence the effect of puberty or growth hormone therapy on glucose homeostasis in short non-growth hormone-deficient small-for-gestational-age children: results from a two-year controlled prospective study. J Clin Endocrinol Metab 2008; 93: 2709-2715. doi: 10.1210/jc.2008-0150

13. De Kort SW, Willemsen RH,van der Kaay DV, et al. Thyroid function in short children born small-for-gestational age (SGA) before and during GH treatment. Clin Endocrinol 2008; 69: 318-322. doi: 10.1111/j.1365-2265.2008.03195.x

14. Schweizer R, Martin DD, Haase M, et al. Similar effects of long-term exogenous growth hormone $(\mathrm{GH})$ on bone and muscle parameters: a pQCT study of GH-deficient and small-for-gestational-age (SGA) children. Bone 2007; 41: 875-878. doi: 10.1016/j. kość .2007.06.028

15. van der Steen, Plundt R, Maas $S$, et al. ACAN gene mutation in short children born SGA and response to growth hormone treatment. J Clin Endocrinol Metab 2017; 102: 1458-1467. doi: 10.1210/ jc. 2016-2941

16. van der Steen M, Annemieke J, Danielle CM, et al. Puberty and pubertal growth in GH treated SGA children: effect of 2 years of GnRHa versus no GnRHa. J Clin Endocrinol Metab 101: 2005-2012. doi: 10.1210/jc.2016-1317

17. van der Steen M, Annemieke J, Danielle CM, et al. Metabolic health in short children born small for gestational age treated with growth hormone and gonadotropin-releasing hormone analog: results of a randomized, dose-response trial. J Clin Endocrinol Metab 2016; 100: 3725-3734.

18. Barker DJ. Fetal programming of coronary heart disease. Trends Endocrinol Metab 2002; 13: 364-368. doi: 10.1016/s1043-2760 (02) 00689-6

19. Jaquet D, Leger J, Levy-Marchal C, et al. Low birth weight: effect on insulin sensitivity and lipid metabolism. Horm Res 2003; 59: 1-6. doi: 10.1159/000067940

20. Levy-Marchal C, Czernichow P. Small for gestational age and the metabolic syndrome: which mechanism is suggested by epidemiological and clinical studies? Horm Res 2006; 65 Suppl 3: 123-130. doi: 10.1159/000091517

21. Arends N, Johnston L, Hokken-Koelega I, et al. Polymorphism in the IGF-1 gene: clinical relevance for short children born small for gestational age (SGA). J Clin Endocrinol Metab 2002; 87: 2720-2721. doi: 10.1210/jcem.87.6.8673

22. Meirhaeghe A, Boreham, CAG, Murray LJ, et al. A possible role for PPARG Pro12Ala polymorphism in preterm birth. Diabetes 2007; 56: 494-498. doi: 10.2337/db06-0915

23. Kajantie E, Rautanen A, Kere J, et al. The effects of the ACE gene insertion/deletion polymorphism on glucose tolerance and insulin secretion in elderly people are modified by birth weight. J Clin Endocrinol Metab 2004; 89: 5738-5741. doi: 10.1210/jc.2004-0492

24. Jaquet $D$, Vidal $H$, Hankard $R$, et al. Impaired regulation of glucose transporter 4 gene expression in insulin resistance associated with in utero undernutrition. J Clin Endocrinol Metab 2001; 86: 3266-3271. doi: 10.1210/jcem.86.7.7677

25. Hansen NS, Hjort L, Broholm C, et al. Metabolic and transcriptional changes in cultured muscle stem cells from low birth weight sub- jects. J Clin Endocrinol Metab 2016; 101: 2254-2264. doi: 10.1210/ jc. 2015-4214

26. Nobili V, Alisi A, Panera N, et al. Low birth weight and catch up growth associated with metabolic syndrome: a ten year systematic review. Pediatr Endocrinol Rev 2008; 6: 241-247.

27. Vaag A. Low birth weight and early weith gain in the metabolic syndrome: consequences for infant nutrition. Int J Gynaecol Obster 2009; 104 Suppl 1: 32-34. doi: 10.1016/j.ijgo.2008.11.026

28. Jaquet $D$, Deghmoun $S$, Chevenne $D$, et al. Dynamic change in adiposity from fetal to postnatal life is involved in the metabolic syndrome associated with reduced fetal growth. Diabetologia 2005; 48: 849-855. doi: 10.1007/s00125-005-1724-4

29. Lakshmy R. Metabolic syndrome: role of maternal undernutrition and fetal programming. Rev Endocr Metab Discord 2013; 14: 229240. doi: 10.1007/s11154-013-9266-4

30. Metrustry SJ, Karhunen V, Edwards MH, et al. Metabolomic signature of low birthweight:pathways to insulin resistance and oxidative stress. PloS One 2018; 13: e 0194316. doi: https://doi.org/10.1371/ journal.pone.0194316

31. Cheong JN, Cuffe JS, Jefferies AJ, et al. Sex-specific metabolic outcomes in offspring of female rats born small or exposed to stress during pregnancy. Endocrinology 2016; 157: 4104-4120. doi: 10.1210/en.2016-1335

32. Cheong JN, Cuffe JS, Jefferies AJ, et al. Adrenal metabolic and cardio renal dysfunction develops after pregnancy in rats born small or stressed by physiological measurements during pregnancy. J Physiol 2016; 594: 6055-6068. doi: 10.1113/JP272212

33. Joung KU, Cataltepe SU, Michael Z, et al. Cord blood adipocyte fatty acid -binding protein levels correlate with gestational age and birth weight in neonates. J Clin Endocrinol Metab 2017; 102: 16061613. doi: 10.1210/jc.2016-3831.

34. Wesolowski SR, Hay WW Jr. Role of placental insufficiency and intrauterine growth restriction on the activation of fetal hepatic glucose production. Mol Cell Endocrinol 2016; 435: 61-68. doi: 10.1016/j. mce.2015.12.016

35. Zhou Y, Gu P, Shi W, et al. MicroRNA-29a induce insulin resistance by targeting PPAR $\gamma$ in skeletal muscle cells. Int J Mol Med 2016; 37 : 931-938. doi: 10.3892/ijmm.2016.2499

36. Vaiserman A, Lushchak O. Prenatal malnutrition induced epigenetic dysregulation as a risk factor for type 2 diabetes. Int J Genomics 2019; 2019: 3821409. doi: 10.1155/2019/3821409

37. Zeng Y, Gu P, Liu K, et al. Maternal protein restriction in rats leads to reduced PGC-1 $\alpha$ expression via altered DNA methylation in skeletal muscle. Mol Med Rep 2013; 7: 306-312. doi: 10.3892/mmr. 2012.1134

38. Peng P, Mia C, Wan S, et al. Inhibition of p53 relieves insulin resistance in fetal growth restriction mice with catch up growth via activating IGFBP3/IGF1/IRS-1/Akt signalling pathway. J Nanosci Nanotechnol 2018; 18: 3925-3935.

39. Xing Y, Zhang J,Wei $\mathrm{H}$, et al. Reduction of the PI3K/Akt related signaling activities in skeletal muscle tissues involves insulin resistance in intrauterine growth restriction rats with catch up growth. PLoS One 2019; 14: e0216665. doi: 10.1371/journal.pone.0216665

40. Jones AK, Brown LD, Rozance PJ, et al. Differential effects of intrauterine growth restriction and a hyperinsulinemic-isoglycemic clamp on metabolic pathways and insulin action in the fetal liver. 
Am J Physiol Regul Integr Como 2019; 316: R427-R440. doi: 10.1152/ajpregu.00359.2018

41. Stalman S, Solanky N, Ishida M, et al. Genetic analyses in smallfor-gestational age newborn. J Clin Endocrinol Metab 2018; 103 : 917-925. doi: 10.1210/jc.2017-01843

42. Diaz M, Garcia C, Sebastiani G, et al. Placental and cord blood methylation of genes involved in energy homeostasis. Diabetes 2017; 66: 779-784. doi: 10.2337/db16-0776

43. Darendeliler F. IUGR: Genetic influence, metabolic problems, enviromental associations/triggers, current and future management. Best Pract Clin Endocrinol Metab 2019; 33: 101260. doi: 10.1016/j. beem.2019.01.001

44. Berends LM, Dearden L, Tung YC, et al. Programming of central and peripheral insulin resistance by low birthweight and postnatal catch-up growth in male nice. Diabetologia 2018; 61: 2225-2234. doi: 10.1007/s00125-018-4694-z

45. Fukami T, Sun X, Li T, et al. Mechanism of programmed obesity: altered central insulin sensitivity in growth restricted juvenile female rats. J Dev Orig Health Dis 2013; 4: 239-248. doi: 10.1017/S204017 4413000019
46. Verkauskiene R, Beltrand J, Claris O, et al. Impact of fetal growth restriction on body composition and hormonal status at birth in infants of small and appropriate weight for gestational age. Eur J Endocrinol 2007; 157: 605-612. doi: 10.1530/EJE-07-0286

47. Simpson J, Smith A, Fraser A, et al. Programing of adiposity in childhood and adolescense: associated with birth weight and cord blood adipokines. J Clin Endocrinol Metab 2017; 102: 499-506. doi: https://doi.org/10.1210/jc.2016-2342

48. Wang Q, Wang XD, Liu X, et al. Effect of intrauterine growth retardation on insulin sensitivity and plasma adiponectin level in neonates. Zhongguo Dang Dai Er Ke Za Zhi 2018; 20: 618-622.

49. Giapros V, Vavva E, Siomou E, et al. Low birth weight, but not catch-up growth, correlates with insulin resistance and resistin level in SGA infants at 12 months. J Matern Fetal Neonatal Med 2017; 30: 1771-1776. doi: 10.1080/14767058.2016.1224838

50. Fruscaizo A, Biasioli A, Londero AP, et al. Retinol binding protein as early of fetal growth restriction in first trimester maternal serum. Gynecol Endocrinol 2013; 29: 323-326. doi: 10.3109/09513590.2012.743013. 